\title{
GUIDELINES FOR GRANTING HOSPITAL PRIVILEGES IN VIDEO-ASSISTED THORACIC SURGERY
}

$\mathrm{T}_{\mathrm{su}}^{\mathrm{o}}$

be granted privileges in video-assisted thoracic surgery (VATS), a surgeon must:

1. Be fully qualified to perform the procedure by the open method and to handle potential complications of the procedure.

2. Document that education in VATS has been obtained. This can be either documentation of attendance at a course that conforms to the guidelines of the Joint Committee on VATS of The Society of Thoracic Surgeons (STS) and The American Association for Thoracic Surgery (AATS) or a letter from the director of the approved thoracic residency program from which the surgeon has graduated. This letter should confirm that the surgeon is qualified to perform VATS procedures on the basis of experience and knowledge about the indications, contraindications, and potential complications. Documentation of education in VATS should remain on file in the administrative offices of the institution that grants privileges.

3. Perform at least five VATS procedures successfully during residency or under observation by a qualified surgeon who certifies the applicant's competence to perform VATS. Whenever possible, the certifying surgeon and the applicant

By prior agreement, this statement is being published both in this JouRnal and in The Annals of Thoracic Surgery.

Address for reprints: Martin F. McKneally, MD, Division of Thoracic Surgery, The Toronto Hospital, Eaton N 10-230, 200 Elizabeth St., Toronto, Ontario, M5G 2C4, Canada.

J Thorac Cardiovasc Surg 1995;110:1574

Copyright (C) 1995 by Mosby-Year Book, Inc.

$0022-5223 / 95 \$ 5.00+0 \quad \mathbf{1 2 / 1 / 6 8 8 6 1}$ should be administratively and economically independent of each other.

4. Provide regular documentation of subsequent VATS cases performed in a manner that is consistent with the policy that governs other operations at the institution that is granting privileges. The outcome of VATS procedures is to be reviewed periodically by the quality assurance committee as required by the department granting privileges.

The criteria listed herein are considered minimal requirements for granting privileges for performing VATS.

This is the final publication from the Joint Committee on VATS, completing the cycle of guideline publications, sponsored courses, and symposia sponsored by the AATS and STS through our ad hoc committee, which was struck in October 1991. VATS is finding its place within the armamentarium, educational programs, and practice of thoracic surgery and no longer requires a special committee. The educational responsibilities of the Joint Committee on VATS will be assumed by the Continuing Education Committee of the STS.

AATS/STS Joint COMmitTee on Video Assisted Thoracic Surgery

Martin F. McKneally, MD, Co-Chairman Ralph J. Lewis, MD, Co-Chairman Richard P. Anderson, MD Richard G. Fosburg, MD William A. Gay, Jr., MD

Robert H. Jones, $M D$

Mark B. Orringer, $M D$ 